\title{
MEMÓRIAS D’ALÉM MAR: ANÁLISE DE NARRATIVAS DE IMIGRANTES PORTUGUESES NO BRASIL
}

\author{
Rosali Maria Nunes Henriques ${ }^{1}$
}

\begin{abstract}
Resumo:
O Brasil foi o principal destino dos portugueses até os anos 60 do século XX. Milhares de portugueses cruzaram o Atlântico em busca de melhores condições de vida. Muitos desses portugueses migraram para o Rio de Janeiro e São Paulo. Nosso objetivo neste texto é analisar as narrativas de alguns desses emigrantes sobre o processo migratório. Com base em vinte e cinco entrevistas de histórias de vida de imigrantes portugueses gravadas pelo Museu da Pessoa e disponíveis no site www.museudapessoa.net iremos fazer um cruzamento entre os temas comuns as narrativas e analisar o processo de integração desses portugueses ao Brasil.
\end{abstract}

Palavras-chave: Imigração. Imigração portuguesa. Narrativas. Memória.

\begin{abstract}
:
Brazil was the main destination of the Portuguese until the 1960s of the 20th century. Thousands of Portuguese crossed the Atlantic in search of better living conditions. Many of these Portuguese migrated to Rio de Janeiro and São Paulo. Our objective in this text was to analyze the narratives of some of these emigrants about the migration process. Based on twentyfive interviews of Portuguese immigrants' life stories recorded by the Museu da Pessoa and available on the website www.museudapessoa.net we will made a correlation between the common themes of the narratives and analyzed the integration process of these Portuguese people to Brazil.
\end{abstract}

Keywords: Migration. Narratives. Memory. Portuguese imigration.

\section{Introdução}

Portugal é um país de emigrantes. Em busca de melhores oportunidades, os portugueses migraram para diversos países durante o século XX. Mas por que uma parte desses portugueses escolheu migrar para o Brasil? Como foi o processo migratório? Como foi a adaptação à nova terra? Quais são as lembranças do que (ou de quem) ficou em Portugal? Por meio das memórias de emigrantes portugueses no Brasil, gravadas em diversos projetos do Museu da Pessoa, viajamos nessa coleção de histórias que retratam o cotidiano e as vivências dos portugueses no Brasil no século XX. A história da emigração pode ser estudada sob vários aspectos e com base em várias fontes, sejam elas escritas (dados censitários, jornais, correspondência, diários etc.),

\footnotetext{
${ }^{1}$ Doutora em Memória Social pela Unirio, pós-doutora pela Universidade de Coimbra e doutoranda em História pela Universidade Nova de Lisboa.
} 
orais e iconográficas (LANG; DEMARTINI, 2008). O uso das fontes orais é uma das fontes a que podemos recorrer para o estudo dos processos migratórios. Ao analisar a importância da História Oral nos estudos sobre emigração é importante alertar que a metodologia de História Oral não é só sobre gravação de entrevistas, mas, conforme apontam Lang e Demartini (2008, p.212), trata-se de "um ponto de confluência de várias disciplinas", uma vez que várias áreas das Ciências Humanas estão envolvidas no processo de coleta e análise das entrevistas. No entanto, é preciso um olhar crítico para a metodologia da História Oral. Abdelmalek Sayad desmistifica o uso das histórias de vida e das biografias, realçando sua importância, mas com o cuidado de analisar a emigração dentro de um contexto histórico com base em outras fontes escritas. Segundo Sayad (1998), é preciso analisar as condições históricas e sociais de que emergem os processos migratórios. Mas podemos também afirmar que a História Oral recupera memórias que não estão presentes nas fontes escritas oficiais. Maria Aparecida Pascal (2005), em sua tese de doutoramento sobre as mulheres emigrantes portuguesas no Brasil, aponta a importância do registro das memórias das mulheres para a construção de uma narrativa sobre a emigração portuguesa no Brasil.

Um dos instrumentos de pesquisa e análise das trajetórias individuais é a microhistória $^{2}$. Ao valorizar os indivíduos e suas experiências pessoais, a micro-história traz à tona as memórias individuais e coletivas presentes nas narrativas, além, é claro, de possibilitar "indagar as estruturas invisíveis dentro da quais aquele indivíduo se articula" (GINZBURG, 1989: p. 177-178). Mais do que uma prática historiográfica, a micro-história possibilita uma análise mais aprofundada, pois "toda ação social é vista como resultado de uma grande negociação, manipulação, escolhas e decisões do indivíduo, diante de uma realidade normativa que, embora difusa, não obstante oferece muitas possibilidades de interpretações e liberdades pessoais." (LEVI,1992, p.135). Dessa forma, ao valorizar a trajetória do indivíduo, a micro-história permite um olhar diferenciado não somente sobre a conjuntura do período, mas também sobre as relações sociais engendradas por ele em seu percurso de vida.

Para analisar as narrativas sobre a emigração portuguesa para o Brasil escolhemos vinte e cinco histórias de emigrantes portugueses, moradores nos Estados de São Paulo e do Rio de

\footnotetext{
${ }^{2}$ A micro-história, que surgiu na Itália nos anos 80, a partir da publicação da série "Microstorie" sob a direção de Carlo Ginzburg e Giovanni Levi, sofreu influência da História Social e da "Nova História". Embora ainda sofrer com o estigma de ser uma "pequena história" (VAINFAS, 2002) e ser muitas vezes confundida com a História das Mentalidades e História do Cotidiano, a micro-história opera em uma escala reduzida de observação, mas pode nos ajudar a entender o universo da emigração com base no olhar dos emigrantes sobre o processo migratório.
} 
Cadernos CERU, Série 2, Vol. 31, n. 1, jun. 2020

Janeiro e cujos depoimentos se encontram disponíveis no portal do Museu da Pessoa ${ }^{3}$. Nosso objetivo principal foi analisar o discurso sobre a emigração, perpetuado por esse grupo específico. Com base nas memórias registradas em depoimentos de história de vida, gravados em diversos projetos do Museu da Pessoa, analisamos as trajetórias de emigrantes portugueses no Brasil. Dois critérios de escolha foram fundamentais nesse processo: selecionamos exclusivamente depoimentos de história de vida e que tinham a transcrição da entrevista no portal do Museu da Pessoa ${ }^{4}$.

Interessava-nos estudar as singularidades das narrativas produzidas pelos emigrantes portugueses no Brasil com base na ótica de deslocamento e da mobilidade dessa população específica. Antes de analisarmos as narrativas propriamente ditas, é preciso esclarecer a base teórica de análise, apresentar o contexto histórico da emigração portuguesa e o perfil dos emigrantes escolhidos para este estudo. Escolhemos para a análise dessas narrativas de memória os pressupostos de Mikhail Bakhtin e seu círculo porque entendemos que a discussão sobre a construção do narrador e da narrativa passa pela subjetividade e pela linguagem e que o autor da narrativa é sempre fruto de um tempo e de um espaço específico.

\section{Perfil dos emigrantes portugueses vindos para o Brasil no século XX}

Para analisarmos o conteúdo dos depoimentos, é preciso em primeiro lugar identificar o perfil desses imigrantes: quem são eles? Quantos homens e quantas mulheres? Em que período migraram para o Brasil? Com quem vieram? Com que idade migraram? Quais familiares moravam no Brasil antes da emigração? E outras tantas questões que poderemos verificar ao longo deste artigo. Embora seja feita com base em um universo de apenas vinte e cinco depoimentos, a amostra é significativa para entendermos o perfil do imigrante português para o Brasil nesse período.

\footnotetext{
${ }^{3}$ O Museu da Pessoa é um museu virtual, criado em 1991, que registra, preserva e divulga histórias de vida de pessoas anônimas na internet. Tem sede física na cidade de São Paulo e seu acervo pode ser consultado online por meio do portal www.museudapessoa.net.

${ }^{4}$ O Museu da Pessoa, assim como outras instituições que usam a metodologia da História Oral, opta por dois tipos de entrevistas: história de vida e história temática. Na história de vida são abordados aspectos gerais de toda a vida da pessoa e por isso apresentam mais informações sobre sua trajetória de vida, enquanto que na história temática são priorizados aspectos ligados a determinado tema. O acervo do Museu da Pessoa disponível na internet está composto por quase 17 mil histórias. A maioria das entrevistas estão transcritas e se encontram disponibilizadas no portal para a consulta de qualquer pessoa.
} 


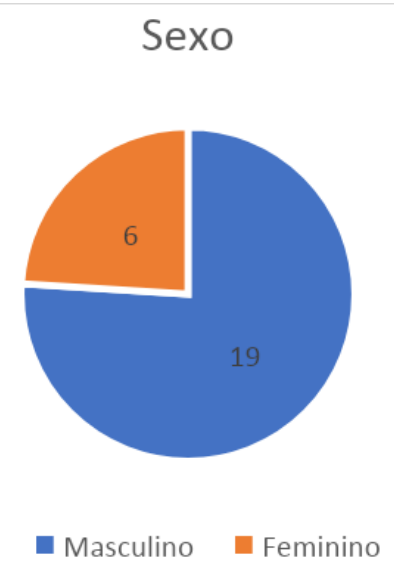

Gráfico 1 - Sexo dos emigrantes

Podemos constatar pelo gráfico acima que o número de homens é bem maior do que o de mulheres. Isso deve ser analisado não somente por esse fator em si, mas levando em conta também a faixa etária e o motivo da emigração. Das seis mulheres entrevistadas, apenas duas emigraram na fase adulta, com os cônjuges. Segundo Menezes e Matos (2017), a desproporção entre homens e mulheres sempre foi alta, embora tenha diminuído ao longo dos anos e essa diminuição foi consequência da emigração familiar no pós Segunda Guerra ${ }^{5}$. No entanto, a maioria dos homens emigrou na fase adulta ou pelo menos com mais de dezessete anos. Para entendermos um pouco mais essa questão podemos ver no gráfico 2 que a maior faixa etária de emigrantes se encontra entre os dezessete e dezoito anos, somando seis pessoas com dezoito anos e três com dezessete, totalizando nove pessoas ao todo, além de cinco pessoas acima dos dezoito anos.

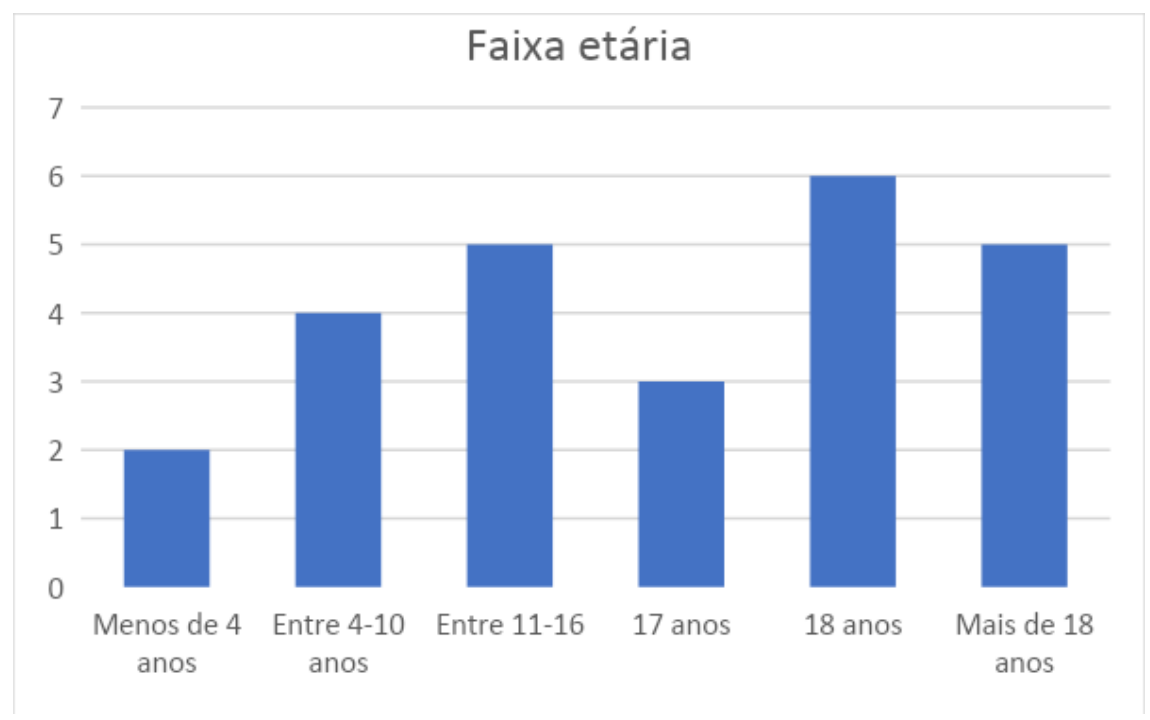

Gráfico 2 - Faixa etária dos emigrantes no momento da migração

\footnotetext{
5 "De $26 \%$ de mulheres em relação aos homens no Censo de $1890,31,7 \%$ no de $1920,36,8 \%$ no de $1940,39,7 \%$ no de 1950 e 41,8\% no de 1960.” (MENEZES; MATOS, 2017, p. 165).
} 
O número maior de homens emigrando na faixa etária entre os dezessete e dezoito anos também pode ser explicado pelo motivo da migração, conforme podemos ver no gráfico 3, no qual podemos verificar que o segundo motivo mais alegado para a emigração é a fuga ao serviço militar obrigatório. Durante o Estado Novo português muitos jovens saíram de Portugal para evitar lutar nas guerras coloniais. Em primeiro lugar, aparece a questão econômica como principal motivação para a mudança. Esse motivo foi alegado por quatorze dos vinte e cinco entrevistados. Nesse número constam não apenas aqueles que emigraram com a família, em busca de melhores condições de vida, mas de homens adultos que decidiram atravessar o Atlântico em busca de trabalho e melhoria de vida. Segundo Menezes e Matos (2017), durante esse período, ao contrário da emigração no século XIX, não havia um padrão específico de deslocamentos, pois muitos eram chefes de família e emigraram anteriormente, enquanto outros emigraram ainda crianças, com a família, e muitas famílias migraram aos poucos.

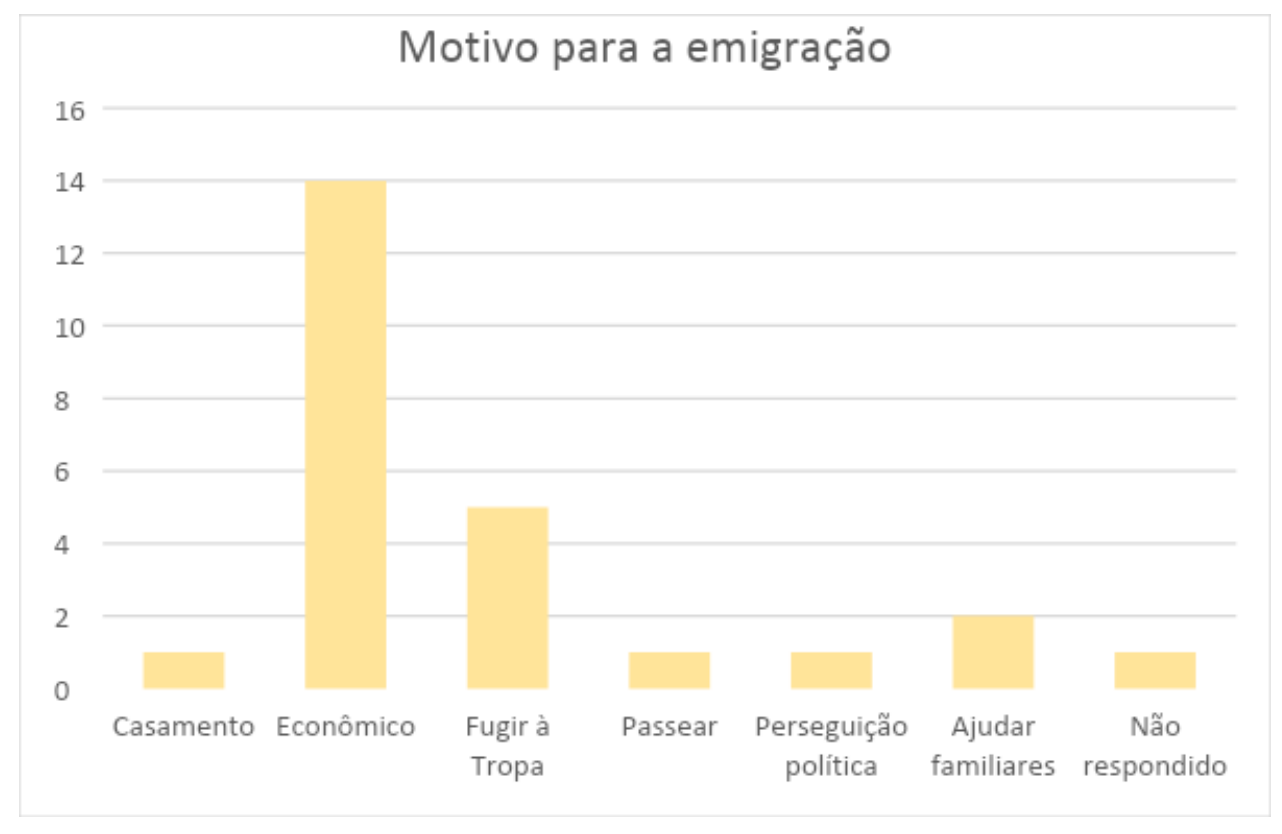

Gráfico 3 - Motivo para emigração

Em relação ao período da emigração, podemos ver pelo gráfico 4 que a maioria emigrou na década de 50 do século XX. Nesse caso, vinte, dos vinte e cinco portugueses entrevistados emigraram nessa década. Conforme vimos anteriormente, nos anos 60, o fluxo emigratório português irá se concentrar nos países europeus, com predominância para a França como destino principal da emigração portuguesa. Podemos ver por esta pequena amostra que, até a década de 50, o fluxo de emigrantes portugueses para o Brasil ainda era muito grande. 


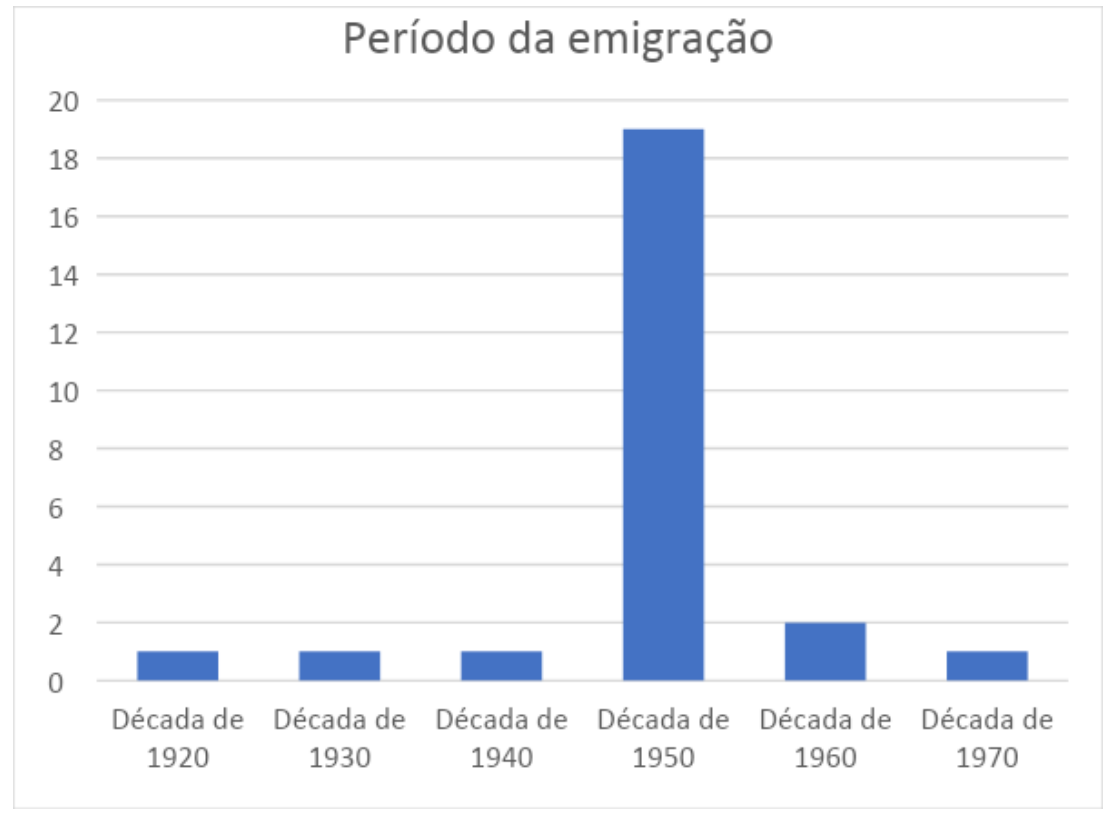

Gráfico 4 - Período da emigração

Em relação à origem dos emigrantes, podemos ver pelo gráfico 5 que todos os entrevistados se concentram nas regiões centro e Norte de Portugal e Ilhas, sendo apenas um emigrante da região de Lisboa e que emigrou por questões políticas. Esses números não são aleatórios, pois sabemos que a grande massa de emigrantes portugueses, mesmo aqueles das levas do século XIX e para outros países eram oriundas das regiões do Norte de Portugal e das Ilhas. No entanto, diferentemente do século XIX, quando a maioria dos emigrantes são da região do Minho, podemos ver, pelo gráfico abaixo, que a região da Beira Litoral é a que mais destinou portugueses para o Brasil nos anos 50. Douro e Madeira encontram-se em segundo lugar no número de emigrantes, seguidos pela região da Beira Alta.

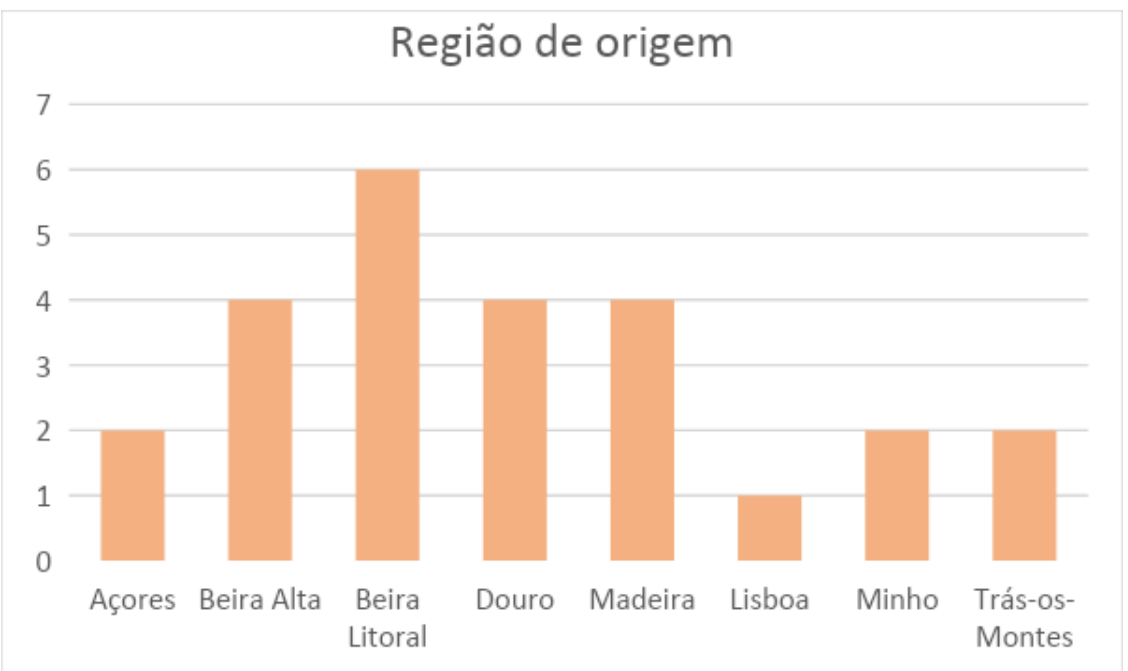

Gráfico 5 - Região de origem 
Em relação à escolha do Brasil como país de acolhimento, a maioria dos emigrantes entrevistados disse que já havia familiares e/ou amigos que moravam no Brasil anteriormente e que a escolha do Brasil deve-se, principalmente, a esse fator preliminar. Segundo Miriam Halpern Pereira (2009), os emigrantes levam em conta os seguintes fatores na escolha do país ou da região para emigração: oportunidades mais promissoras, acesso e instalações mais fáceis. No entanto, mais do que essas oportunidades, a questão da língua e das relações familiares são fatores importantes no processo, pois a escolha do local de acolhimento está intrinsecamente ligada às redes familiares. Oswaldo Truzzi (2008) discute a importância das redes familiares que se formam no país de destino e que são primordiais na escolha deste ou daquele país no momento da emigração, apontando esse fator como "variável-chave" na escolha. E essas redes não se restringem ao ambiente familiar, abrangendo algumas vezes aldeias inteiras, no que Truzzi (2008) apresenta como uma espécie de "contágio da febre migratória”. A emigração portuguesa para o Brasil na década de 50 do século XX foi marcada por essa estratégia, pela qual um elemento da família e ou do grupo de amigos migrava primeiro e posteriormente enviava cartas de chamadas e/ou recursos financeiros para outros membros emigrarem. Essas redes familiares acabavam por atrair novos emigrantes não só para o país de acolhimento, mas para uma cidade específica, tendo durante esse período a grande concentração de emigrantes portugueses sido direcionada para as cidades do Rio de Janeiro e São Paulo. Entre os vinte e cinco entrevistados, podemos ver, pelo gráfico 6, que a maioria tinha uma rede familiar no Brasil, tendo, no caso de dez deles, o pai já residência no Brasil no período da migração. Outros disseram que os tios, primos e irmãos já moravam no Brasil, o que facilitou a escolha do país. Entre os entrevistados, uma mulher migrou para encontrar o marido no Brasil e uma migrou com o marido, mas já tinha um cunhado morando aqui. Apenas dois emigrantes não possuem membros da família morando no Brasil, ambos por motivos políticos. 


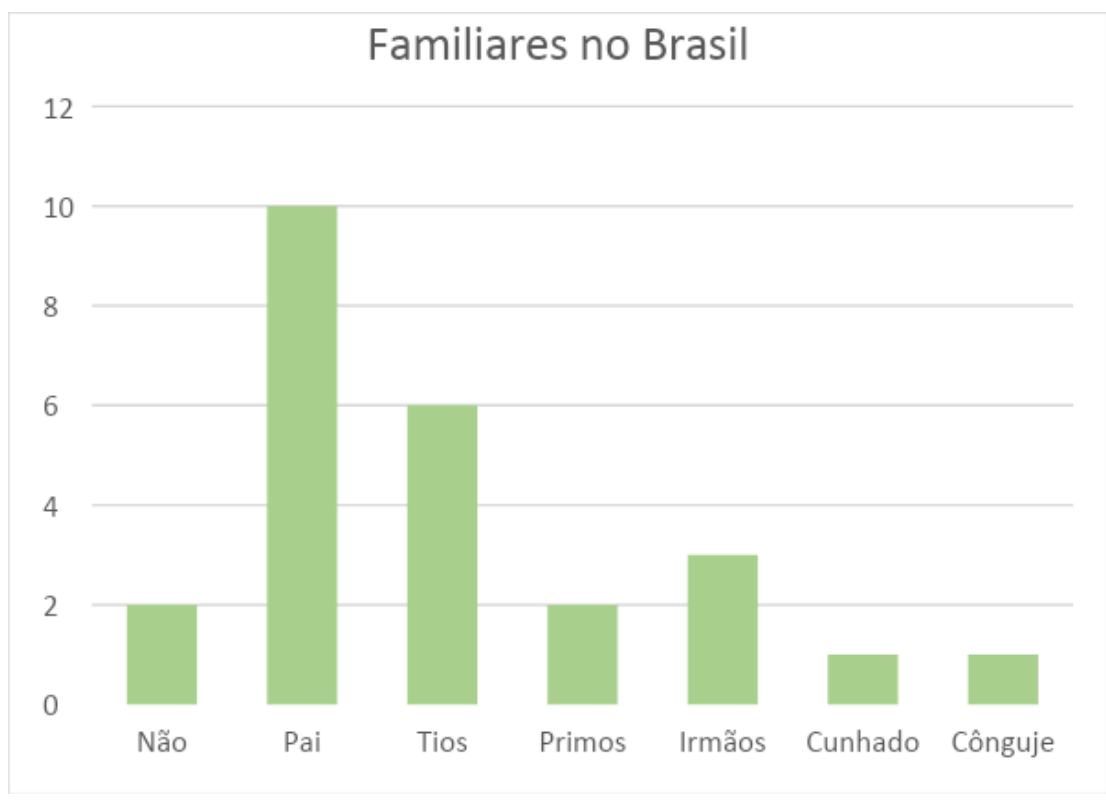

Gráfico 6 - Rede familiar no Brasil

\section{Narrativas sobre a emigração}

As entrevistas, gravadas pelo Museu da Pessoa entre os anos de 1994 e 2013, são de história de vida e, portanto, abrangem todos os aspectos da vida dos entrevistados. Mas o que essas pessoas têm em comum? $\mathrm{O}$ fato de serem emigrantes portugueses que trocaram Portugal pelo Brasil e que construíram uma trajetória na nova pátria. No entanto, os temas que nos interessam para análise são ligados à emigração tais como: origem, histórias da infância e/ou adolescência em Portugal, motivação para a migração, escolha do Brasil, processo migratório e adaptação à nova realidade, construção de uma identidade híbrida entre Portugal e Brasil e as percepções sobre Portugal. A seguir analisaremos os temas mais recorrentes com base nas narrativas produzidas durante as entrevistas.

\section{As lembranças de infância e de um Portugal que ficou para}

trás

Em seus depoimentos, os emigrantes entrevistados conservam sempre a memória de uma infância pobre, mas feliz, em sua aldeia de origem. As lembranças dos trabalhos domésticos e no campo, principalmente da mãe, se perpetuam nas memórias da infância:

Eu via minha mãe amassar o pão com as mãos. As farinhas de milho e trigo, se via amassar o pão no tabuleiro, e a gente via que depois aquilo ia para uma masseira coberta com uma toalha e crescia. Jogava o fermento. O fermento era um pouco de massa da outra semana. Manuel dos Santos Paiva, nascido em Gildinho, Castelo de Paiva, em 1929.

Desde que eu tinha mais ou menos cinco ou seis anos de idade eu já estava andando pelo mar, inclusive junto com os meus irmãos e meu pai. Os meus 
pais tinham arrastão. António Alves da Rocha Guimbra, nascido em Espinho, em 1920.

O que eu me lembro é que minha mãe cozia pão, fazia pão. Então tinha um forno. Porque era uma casa alugada de uma senhora lá. E aí ela também cozia o pão dela no sábado, era um dia por semana que se botava lenha, o forno. $\mathrm{E}$ também me lembro de coisas agrárias assim. Tinha um tal de um negócio de desfolhada, que era um negócio de milho. Na hora da colheita do milho, a gente cantava e fazia festa a noite toda. E ficava todo mundo desfolhando o milho. Então todo mundo plantava, porque era uma região que todo mundo plantava. Tinha uva, tinha horta. Perfeito António Fortuna Serra Lopes, nascido em Serzedo, 1950.

A maioria dos emigrantes veio de aldeias pequenas, de um ambiente rural e com costumes e tradições do campo. Apenas um dos emigrantes veio de uma grande cidade: Lisboa. Em suas entrevistas, eles relatam as atividades no campo, na colheita da azeitona, na produção do vinho e como eram diferentes as atividades desenvolvidas nas aldeias de origem e nas cidades em que foram morar no Brasil.

Para colher azeitona é só colocar uma coberta no chão e, com um bambu, bater no pé de azeitona e elas caem na coberta. Depois pegamos a azeitona e fazemos o que nós chamamos de lagar, que é uma prensa onde se colocavam as azeitonas, um moinho que fazia o azeite. Isso antigamente, hoje em dia é tudo automático. O azeite normalmente é o Beira Alta, como chamam na minha terra. Nós só fazíamos o azeite para o nosso uso e vendíamos as azeitonas a quilo, as pessoas faziam o azeite depois. Nós comíamos muita carne de porco, porque matavam muito, uns porcos imensos. E lá não precisava de geladeira, porque era muito frio. Na minha infância nós tínhamos fogão a lenha e colocávamos aquelas linguiças e o presunto para defumar. Era uma coisa que guardávamos para o ano todo, matavam dois, três porcos grandes por ano. Nós tínhamos quase tudo, só não tínhamos arroz e sal. Nós plantávamos quase tudo. Tínhamos uma horta, o azeite, vinho, feijão... Almerinda Lourenço Pontes, nascida em Vilar do Monte, em 1956.

A gente fazia linguiça em casa. Quando matava um porco fazia a linguiça, fazia o chouriço, fazia o salpicão. Fazíamos chouriço com o sangue do mesmo porco. Matava uma vez por ano. Abel Gonçalves, nascido em Lamego, em 1921.

A gente colhia o azeite, o tempo de pegar o azeite é em dezembro, a azeitona, que é no tempo do frio. Muito frio, muito frio. A gente queria pegar azeitona do chão, as mãos da gente nem conseguia, porque encolhia. É bonita a colheita de azeitona. Dependendo do olival, que chama olival. Onde tem as plantas do pé da azeitona se fala olival. Então tem oliveiras grandes, tem oliveiras menores. As grandes, nós tínhamos que subir numa escada e ripar, sabe? Puxar pra baixo. Embaixo punha um toldo assim no pé da oliveira para a azeitona cair no toldo. E as mais altas, que a gente não alcançava, eles usavam umas varetas, umas varas, pra bater pra azeitona cair. Clarisse Diniz Paiva, nascida em 1933, em Carregal do Sal.

Os emigrantes saíram, na sua maioria, de pequenas localidades do Norte e Centro e das

Ilhas de Portugal para as duas maiores metrópoles brasileiras: as cidades de São Paulo e Rio de Janeiro. Nos anos 50 do século XX, a cidade de São Paulo possuía mais de 2 milhões de pessoas 
Cadernos CERU, Série 2, Vol. 31, n. 1, jun. 2020

e a cidade do Rio de Janeiro, que era capital do país naquela ocasião, contava com 2,3 milhões ${ }^{6}$. Essas memórias de infância, carregadas de nostalgia, apresentam um Portugal rural e em alguns casos ainda bem diferente da realidade das grandes metrópoles brasileiras.

\section{O papel das redes familiares na escolha do Brasil}

Conforme vimos anteriormente, a escolha do país para migrar não é aleatória. A rede de familiares existentes no país de acolhimento é um fator primordial na escolha do local para a migração. A emigração portuguesa para o Brasil na década de 50 do século XX é marcada por essa estratégia, na qual um elemento da família ou do grupo de amigos migrava primeiro e posteriormente enviava cartas de chamadas e/ou recursos financeiros para outros membros migrarem. Essas redes familiares acabavam por atrair novos emigrantes não só para o país de acolhimento, mas para uma cidade específica, tendo durante esse período a grande concentração de emigrantes portugueses sido direcionada para as cidades do Rio de Janeiro e de São Paulo.

Eu tinha primos em segundo grau no Brasil. Eu acho que eles vieram por aquela vontade de conhecer o mundo. É, digamos assim, uma espécie de febre de que começa a fazer as pessoas querem emigrar, sendo que, o português, sempre teve muito essa coisa de imigrante, de migrar. Artur Leite, nascido em Souto, em 1934.

Eu ia nascer no Brasil, a minha mãe estava grávida e vindo pro Brasil, quando chegou no Porto, não a deixaram embarcar porque a viagem era bastante demorada, alguns dias. E aí ela acabou retornando e eu nasci em Portugal. Depois de seis meses eu vim para cá. $\mathrm{O}$ meu pai veio nessa viagem, na frente da minha mãe. Tinha um irmão dele que já tinha vindo para cá e ele resolveu então deixar essa vida mais simples que tinha e veio tentar uma nova vida aqui no Brasil, em São Paulo. António Alberto Saraiva, nascido em Celourico da Beira, em 1953.

Dessa forma, entendemos que as redes familiares são uma chave para o entendimento não só do processo migratório como do processo de regresso dos emigrantes portugueses. As redes familiares construídas no Brasil pelos portugueses remontam ao século XIX, com fluxos de ida e de vinda durante todo o século XIX e século XX, que continuam a exercer papel importante nas migrações atuais entre os dois países. Alguns dos emigrantes, como as famílias de António Hermínio Lopes e Manoel Horácio da Silva, já possuíam raízes brasileiras mais sólidas:

Meu pai era funcionário público alfandegário na Ilha Terceira. E a minha mãe era doméstica. $\mathrm{O}$ meu avô materno era brasileiro e filho de imigrantes açorianos. Passado algum tempo, ele foi para Açores com a família e montou uma loja. Tenho dois tios brasileiros, que já morreram, nascidos na Rua do Mattoso, batizados na Igreja São Francisco Xavier. António Hermínio Garcia da Rocha Lopes, nascido em 1944, na Ilha Terceira, nos Açores.

Pelo que sei, meu avô veio no início do século retrasado trabalhar na construção de estradas de ferrovias. Trabalhou alguns anos e voltou. Mas

\footnotetext{
${ }^{6}$ Dados do Censo de 1950 do IBGE - Instituto Brasileiro de Geografia e Estatística.
} 
nunca trouxe a família. Meu pai é que imigrou em 1947, trazendo toda a família. Manoel Horácio Francisco da Silva, nascido em 1945, em Aveiro.

Conforme vimos anteriormente, no caso da maior parte dos emigrantes, o pai veio primeiro, com base no contato com familiares e amigos que já moravam no Brasil e acumulou recursos para trazer a família, como é o caso, por exemplo, de Abel Gonçalves e de Maria Augusta Alexandre:

Primeiro veio a minha tia, que era tia e madrinha minha. Então ela resolveu trazer meu pai. Depois de um tempo nos chamou, que eram os dois mais novos porque nós não pagávamos taxa de soldado. Os mais velhos já pagavam uma taxa. Eu tinha 12, com 14 anos já não viaja. Pra viajar tem que pagar aquela taxa de exército. Meu pai ficou uns oito anos fora de Portugal. Eu fiquei oito anos sem ver meu pai e 15 anos sem ver minha mãe. Depois de 15 anos veio a família toda. Abel Gonçalves, nascido em Lamego, em 1921.

Quando eu vim para o Brasil, meu pai já estava cá há um ano. O meu pai foi à África fazer o serviço militar e quando voltou, queria trabalhar, mas lá não tinha meios, então ele veio pro Brasil. Ele era filho único. Não sei de nada da minha família, da família do meu pai. Ele não tem irmãos, não tem tios, não tem ninguém. Maria Augusta Lopes Alexandre, nascida no Funchal, Ilha da Madeira, em 1913.

Ao analisarmos os perfis dos entrevistados vimos que apenas dois dos vinte e cinco emigrantes não possuíam redes familiares no Brasil. São eles: Manuel Henriques Farias Ramos e Fernando Lemos e ambos vieram fugindo do salazarismo, estando o primeiro também fugindo ao serviço militar obrigatório:

A minha escolha de vir para o Brasil também tem um detalhe interessante. Eu li um livro de Stefan Zweig, "Brasil, País do futuro", e eu me apaixonei pelo Brasil. Eu tinha parentes nos Estados Unidos, mas não tinha ninguém aqui. Eu sou brasileiro antes de vir para o Brasil. Eu tinha o espírito um pouco rebelde, questionava a ditadura de Salazar e então já pesava sobre mim uma certa ameaça d, a qualquer altura, ter alguma penalidade mais grave. $\mathrm{E}$ ao mesmo tempo começava-se a guerra nas colônias. Pra quem tinha uma visão crítica em relação ao sistema, a última coisa que eu poderia aceitar era ir para a guerra das colônias, era contrário de tudo aquilo que eu sentia e pensava. Então só tinha uma maneira: ou eu pegava e ia arriscar a minha vida nas colônias por aquilo que eu não acreditava, ou eu migrava. Então não houve escolha, meus pais concordaram porque também não havia escolha, o risco era conhecido. Manuel Henriques Farias Ramos, nascido na Ilha Terceira, Açores, em 1939. Vim pra São Paulo, foi com isso do IV Centenário que eu me integrei. Aí pensei em casar, ter filho, essas coisas. E não voltei mais. Me liguei a tudo que era exilado político, portugueses e espanhóis. Então fiquei mais condenado ainda. Eu fiquei proibido de entrar em Portugal, o que pra mim foi ótimo, e só voltei quando foi a Revolução dos Cravos em 1974. Aí passei a ir lá quase todos os anos e às vezes vou duas vezes porque me integrei de novo na vida artística lá. Então hoje eu estou dividido. Fernando Lemos, nascido em Lisboa, em 1926. 


\section{A fuga à tropa}

Como vimos anteriormente, um dos principais motivos dos portugueses migrarem para o Brasil durante esse período era para evitar o serviço militar obrigatório. Mesmo antes do período das guerras coloniais, a exigência de servir durante até cinco anos o exército nas colônias africanas não atraía os jovens que preferiam emigrar a servir à tropa. Cinco dos portugueses entrevistados apontam claramente esse motivo de terem migrado para o Brasil. Nesse número não estão contabilizados aqueles que vieram com os pais.

A minha vinda para o Brasil foi para me livrar do exército. Não queria servir por causa da guerra colonial, já que poderia ficar até cinco anos no exército. Tentei ir para os Estados Unidos, mas não consegui, porque era muito difícil naquela época. E a minha opção foi vir para o Brasil. Eu queria vir para cá e ficar uns dez anos. Mas a ideia é uma coisa, depois as consequências são outras. A minha partida foi muito dolorosa. Só tinha minha mãe e irmãos. Senti um rasgar no coração, no peito, chorei muito. Fiquei 18 dias em Lisboa para cuidar da papelada." António Hermínio Garcia da Rocha Lopes, nascido em 1944, na Ilha Terceira, nos Açores.

Eu resolvi vir para o Brasil precisamente pela fama que o Brasil tinha de bom lugar para se ganhar dinheiro. E, depois, nessa época estavam acontecendo as guerrilhas em nossas colônias de Angola e Moçambique e quase todo mundo era obrigado a servir o exército, ir pra tropa. Quando nós íamos para a tropa as mães choravam muito, era um desespero danado nas famílias, ainda mais nessa época quando estava a guerra em Angola e Moçambique. Em dois anos de serviço militar tinha que servir quatro, e você fazia a recruta em Portugal e depois ia para as colônias brigar com os negros. E não sabia se voltava. José Pereira Correia Lopes, nascido em 1939, em Viana do Castelo

$\mathrm{Na}$ época eu tinha um tio que trabalhava aqui em Vicente de Carvalho, ele tinha um açougue. E eu, quando eu resolvi me ausentar, quando eu resolvi que não queria servir a vida militar em Portugal, pelo fato de ver gente voltando mutilada e outros mortos, eu resolvi: "Eu não vou enfrentar isso, eu não quero essa vida, eu vou embora." Então escrevi para meu tio, naquele tempo não havia ligações, o telefone era caro ou tinha poucos telefones também, eu escrevi para meu tio e disse a ele que queria me ausentar de Portugal, por esta razão. E ele me mandou duas cartas daqui me desaconselhando completamente de vir pra cá, porque o Brasil estava muito mal, isso aqui estava na época da Revolução, foi no ano que antecedeu a Revolução de 64, greves todo dia, não sei o quê. Eu voltei a escrever, dizendo a ele que eu de qualquer maneira queria vir, fosse que situação fosse, eu não ia servir o exército e procurava ir para um país onde se falasse a língua portuguesa, seria mais fácil. Armênio Mendes, nascido em 1944, em Chão de Couce.

\section{Cruzando o Atlântico: a viagem}

Até os anos 60 do século XX, as viagens eram feitas de navio e demoravam muito tempo. A maioria dos imigrantes nunca havia viajado de navio, muito menos para tão longe. Por ser uma viagem tão longa e pela falta de costume, todos se lembram bem desse evento que marcou a sua infância e/ou adolescência. Os enjoos, as comidas diferentes e as distinções de classe nos navios marcam as lembranças dos emigrantes: 
Eu vim em um navio francês chamado Claude Bernard. Naquela época vinha todo mundo de navio, o que é maravilhoso. $\mathrm{E}$ a gente veio na terceira classe porque os navios eram divididos: primeira, segunda, terceira classe. A gente veio, classe super humilde onde as mulheres eram divididas dos homens. Os homens dormiam em uma parte e as mulheres dormiam em outra, mesmo sendo casados. Cláudia Lage Botelho, nascida em 1949, em Vila Real.

Levamos três meses de viagem. Estava sempre andando, não tinha sossego porque não tinha para onde ir. E eu me perdi no navio. Minha mãe andou perguntando se alguém tinha me visto e ninguém viu. Aí, me pegaram e levaram pra primeira classe. Maria Augusta Lopes Alexandre, nascida na Ilha da Madeira, em 1913.

Esse navio estava uma carroça já velha. Levou quase 15 dias. Eu gostei imensamente das comidas, tratavam a gente muito bem. Nós viríamos de $3^{\mathrm{a}}$ classe. Sabe onde é a $3^{a}$ classe? É nos porões Mas era navio de passageiro, não era junto com carga. Só vinham as nossas malas e as malas das pessoas que vinham de Lisboa. Meu marido pagou na agência, na última hora, e viemos de $2^{\mathrm{a}}$ classe. Tínhamos um camarote com ventilador, guarda-roupa. Viemos muito bem mesmo. Pra mim foi um paraíso. Eu gostava de ficar no convés pra ver o mar e o azul do céu. Era tão bom, eu achei maravilhoso. Beatriz de Leão Pereira, nascida no Funchal, Ilha da Madeira, em 1924.

A viagem foi péssima até a Madeira. Enjoei, não podia nem olhar para as coisas, ficava tudo embrulhado. Cheguei na Madeira, comprei uma cadeira dessas de vime, que a gente deita para dormir, e comprei um cacho de bananas porque eu tinha medo de enjoar. E três dias depois já tinha tudo passado, porque é assim mesmo que passa. Eu estava com 18 anos e vim sozinho. Encontrei pessoas amigas. Eu vim em 1942, na Segunda Grande Guerra. Não vi uma mosca, nem um avião sobrevoando, não se viu nada. Portugal era neutro naquela época, estava fora da coisa. Joaquim Cabral Guedes, nascido em Maia, em 1924.

No caso de António Guimbra, as recordações da viagem não são muito boas porque o

filho adoeceu e morreu logo que chegou ao Brasil:

A viagem durou 14 dias e meu filho morreu no outro dia que eu cheguei. $\mathrm{O}$ menino tinha seis, sete meses. Ele ficou doente no navio. Veio muito bem até o Equador. Depois, como o calor era demais, as águas eram ruins e ele não mamava no peito da mãe porque a mãe não tinha alimento suficiente para alimentar o menino. E ele por causa das águas deu bronquite pneumonal, desidratação, ficou fraco... Foi ao médico, mas não adiantou. No outro dia de manhã, às cinco horas da manhã mais ou menos, ele morreu. António Alves da Rocha Guimbra, nascido em 1920, em Espinho.

\section{A chegada no Brasil e a adaptação à nova realidade}

A migração é sempre um processo de desenraizamento, de mudança e de deslocamento. É sempre um começar de novo. As mudanças de país nem sempre são fáceis. Aqueles que vieram sozinhos tiveram mais dificuldades em se adaptar do que quem veio com a família. Nem sempre as redes familiares eram suficientes para que o emigrante se sentisse em casa. E, em alguns casos, como o de Manuel de Santos Paiva, o primeiro contato com o Brasil foi desesperador porque o primo esqueceu de buscá-lo em Santos:

Cheguei em Santos. Em cima do navio, todo mundo olhando pra baixo. Cumprimentando os de cima, os de baixo, uns contentes. E eu de cima do 
navio, não via o primo, não via ninguém. Não me estavam esperando, não tinha ninguém. Eu desci, cheguei em baixo, cadê o primo? Não tem primo. E agora aqui no Brasil, não tem primo, não tem conhecidos. Eu não tinha como tirar as malas, pra pagar a alfândega, porque ali precisa pagar. Não tinha cruzeiro, só tinha escudo. Um senhor é que falou pra mim: "Vai a esse guichê e troca escudo pelo dinheiro brasileiro". Só que quando puseram as malas na calçada de fora, estava escuro já. Aí eu comecei a chorar. Chegar ao Brasil, a uma terra estranha, não tinha família, não tinha dinheiro do país e agora de noite... O senhor é que falou: "Olha, pega aqui o bonde número tanto" - os bondes que se usava. "O bonde que passa aí, número tanto". - escreveu no papel - pega o bonde e paga não sei quanto. Era um dinheiro pequeno. "E vai descer numa rodoviária. $\mathrm{O}$ bonde leva até lá a rodoviária onde tem os ônibus que levam a São Paulo". Aí eu entrei no bonde. Cheguei na rodoviária, entrei num ônibus, subi a serra de Santos. Tudo era escuro, uma escuridão e cheguei no ponto final. Era na Praça João Mendes. Aí era aonde os ônibus de Santos encostavam naquela época. Terminou com os passageiros a descer e agora um senhor passageiro falou: "O senhor agora vai descer em São Paulo e pega um táxi”. Dei o endereço, que eu tinha em Portugal, e cheguei à padaria. O meu primo estava a dormir, no segundo andar. A padaria era embaixo. Os sócios fizeram-me lanche de pernil, gostoso pernil, oh diacho... tomei um guaraná. A primeira vez. Não conhecia o guaraná. Só conhecia o vinho de Portugal. Então aí deram-me esse lanchinho, subi as escadas, levaram-me ao quarto onde eu ia dormir, aonde o meu primo já estava a dormir, em uma das camas, assim pegada. Toca a conversar... De manhã, às 2 horas da madrugada ele levantou-se para ajudar a fazer o pão. E a vida foi esta. Manuel dos Santos Paiva, nascido em Gildinho, Castelo de Paiva, em 1929.

Para quem migrou sozinho a pior parte, além do desenraizamento, foram as saudades do convívio familiar que deixou em Portugal. É um longo processo até se acostumar a não participar das festas da família e a sofrer com as distâncias, principalmente num período onde a comunicação era feita basicamente por cartas.

Muitas vezes fugi para o fundo do armazém pra arrumar garrafa vazia, chorei pra caramba, mas aguentei a pressão, eu tinha 17 anos. A gente tinha muita vontade de voltar, mas eu acho que até o brio não deixava. A gente viveu sempre junto ali a família, irmãos, primos, tios, pai, mãe e sair sozinho pra um lugar sem ninguém, sem conhecido, só esse primo ou dois primos e só e mais nada. É bravo mesmo, só com o tempo mesmo que a gente se acostuma com a vinda ao Brasil, afinal a gente saí do seio da família, do conforto que a gente, conforto em termos, não conforto de diversão etc., mas conforto de alimentação de não faltar era roupa, dinheiro, nunca tínhamos, graças a Deus, e você se vê num local sem família, sem parentes, sem dinheiro. Artur Leite, nascido em Souto, em 1934.

Ao falar sobre processos migratórios é preciso estudar o fenômeno da integração que deriva dos conceitos de acomodação e assimilação do emigrante à nova terra. Segundo José Jobson Arruda (2009), não podemos discutir esses conceitos sem entender os processos sociais e culturais que derivam da dinâmica da emigração, pois eles estão ancorados em realidades diferentes e que entram em choque durante o processo migratório. Assim, o estranhamento é normal, mas aos poucos os imigrantes vão se adaptando à nova realidade e adquirindo os costumes da nova terra, tal como comer feijão preto, por exemplo: 
Eu estranhei muitas coisas. Principalmente quando eu precisava sair na rua para comprar alguma coisa e os nomes eram totalmente diferentes. E aí ficava sem saber o que fazer... Eu falei para o meu marido que nunca ia comer feijão preto: "Que feijão preto o quê, menino. Na minha terra não tem isso". E hoje eu sou fã de feijão preto. Quando eu disse para as pessoas que ia me casar e vir para o Brasil, me achavam maluca, que eu não conhecia ele direito, mas todo o trabalho do meu marido estava aqui. Eu não sabia o que é que encontraria aqui. Irene Maria Gomes Baranda, nascida em Chaves, em 1944.

\section{Olhares sobre Portugal após a migração}

A relação dos emigrantes com Portugal é na maioria das vezes uma relação idílica, formada apenas pelas lembranças da infância, uma vez que muitos deles nunca mais voltaram a Portugal, nem a passeio. Monteiro (1994) afirma que a maioria dos estudos sobre a emigração portuguesa aponta para uma mitificação do país de origem, ao afirmar que o emigrante português só opta por uma outra nacionalidade quando é "forçado" pelas circunstâncias. Para desmistificar essa visão, Monteiro propõe três alternativas teóricas: diferenciar o êxodo da emigração, em segundo lugar ele aponta que há uma falsa questão em relação à fixação do emigrado à terra de origem e isso deve ser levado em conta nos estudos sobre o regresso. E por fim, Monteiro questiona o conceito de comunidade usado para designar as comunidades portuguesas no exterior, uma vez que induz a existência de laços fortes entre os emigrantes quando na verdade não há esses laços, digamos, "naturais", entre os portugueses no país de acolhimento. Monteiro (1994) afirma que a maior parte dos emigrantes mantém uma ligação simbólica com Portugal, como o uso de bandeiras, nomes de batismo etc., numa espécie que ele chamou de "folclorização da cultura de origem".

Alguns dos entrevistados frequentam as atividades das associações portuguesas e incentivam os filhos a também participarem e conhecerem a cultura portuguesa, tal como nos aponta António Lopes:

Meu filho frequenta a Casa dos Açores, mas já participou mais. Ele dançava no grupo folclórico. Ainda dança, mas de vez em quando falha. Namora uma filha de açorianos, que está se formando em dentista. A menina mora longe, em Nova Iguaçu, então fica mais difícil participar muito da Casa. Mas ele ainda vai. Agora mesmo tem um grupo de açorianos passeando no país, estão morando lá na Casa dos Açores. E ele foi com eles para mostrar o Maracanã. Nós ouvimos pouca música em casa, gosto mais da televisão. Sou vidrado na RTPI, um canal português, que tem jornal açoriano, notícias de Portugal. António Hermínio Garcia da Rocha Lopes, nascido em 1944, na Ilha Terceira, nos Açores.

Marta Rosales (2015), que analisou trajetórias de famílias portuguesas que moravam em Moçambique e retornaram a Portugal após o 25 de abril, ressalta a questão identitária nos processos migratórios. Ao estudar os objetos trazidos pelos portugueses, residentes em Moçambique e que foram para Portugal nesse período, Rosales (2015) aponta a importância da 
identidade cultural portuguesa, preservada entre os portugueses naquele país, mesmo tendo muitos deles pouco (ou nenhum, em alguns casos) contato com Portugal. Em contradição com o que ela afirma, alguns dos entrevistados dizem não manter as tradições portuguesas e que as relações com Portugal estão cada vez mais distantes, tais como aponta Manuel Rodrigues, por exemplo:

Nossa tradição é aqui. A nossa tradição é paulista. De Portugal não tem mais nada. Sou mais paulista que português. Estou vivendo aqui. Estive na minha terra faz cinco anos da última vez. Primeira vez foi em 81. Eu estava aqui fazia 30 anos. Quando voltei lá depois de 30 anos longe, senti pouca coisa. Nem me senti emocionado... Na primeira vez, encontrei todo mundo. Agora cheguei lá não encontrei ninguém. Tinha morrido tudo. Só tinha uma tia lá, morreu também depois que eu vim pra cá. Agora só tenho primos lá. Então, vou passear e volto. Manuel Fernando Rodrigues, nascido em Ribeira Brava, Madeira, em 1934

Para aqueles emigrantes que nunca voltaram à terra natal, o choque é a descoberta de que o Portugal rural que deixou para trás não existe mais, uma vez que as aldeias e pequenos vilarejos onde moravam se transformaram durante o período em que estiveram longe. $\mathrm{O}$ Portugal extremamente rural e pouco desenvolvido que conheciam ficou para trás após a entrada na União Europeia e os incentivos para o crescimento nos anos 80:

Eu vou descobrir talvez em setembro ou agosto, porque eu vou para Portugal esse ano. Vai ser a primeira vez, depois de 35 anos. Eu sei que tem muita mudança, porque eu tenho contato com pessoas que vêm de lá e me disseram que lá está muito mudado, para melhor. Só vou poder ir agora, porque meus filhos eram pequenos e agora que estão grandes, e tenho um tio que também vai lá, resolvemos ir este ano. Já está mais do que na hora. Ficar 35 anos sem ir lá é muito tempo, uma vida. Eu acho que tudo tem a sua hora e tenho certeza que deve ter alguma coisa reservada para mim, vou ver muita novidade lá. Almerinda Lourenço Pontes, nascida em Vilar do Monte, em 1956.

Eu fiquei muitos anos sem ir a Portugal. Eu vim para o Brasil e só voltei a Portugal quando tinha 18 anos, por imposição do meu pai. Eu queria um Volkswagen na época e ele me deu uma passagem para Portugal. Ele queria que eu conhecesse, queria mostrar Portugal. Aí depois eu fiquei muitos anos sem ir a Portugal, não me interessava mais por Portugal. Na verdade, eu sempre me considerei brasileiro. Eu sou casado com brasileira, meus filhos nasceram aqui, eu não tinha nada a ver com Portugal. Mais recentemente, estou falando de uns 12 anos atrás, talvez 15, eu fui a Portugal, na verdade eu fui à Espanha e aí eu falei: "Não custa nada eu dar uma chegada em Portugal". Aluguei um carro e fui a Portugal e tive um choque muito grande. Portugal para mim naquela época era um lugar muito feio, muito feio. As cidades eram feias, escuras, eram sujas, as construções todas pretas eu tomei um choque também e de certa forma eu me desinteressei de novo por Portugal. Eu voltei a me interessar por Portugal faz uns oito anos. João Augusto Reverendo de Miranda, nascido em São Jacinto, em 1943.

Experiência diferente, por exemplo, foi a de Manoel Horácio da Silva que voltou a viver em Portugal durante seis meses quando da doença da mãe. A experiência marcou sua infância, pois ele não tinha lembranças da terra natal porque veio com um ano de idade: 
Cadernos CERU, Série 2, Vol. 31, n. 1, jun. 2020

Foi interessante essa temporada em Portugal. Minha mãe foi para lá comigo, eu sou o irmão do meio, e o mais novo. Meu pai ficou com meu irmão mais velho em São Paulo. Minha mãe tinha uma doença e como São Paulo naquela época era muito úmida, os médicos falaram que ela se curaria se fosse para o clima seco. O clima seco na memória deles seria a terra natal deles. Então nós fomos pra lá e, pra mim, foi uma coisa muito interessante porque eu reencontrei um mundo que eu não conhecia, cheio de primos. Vivendo no Brasil era só nós mesmo. Era eu meu pai, minha mãe e meus irmãos. Nós não tínhamos família no Brasil e lá todo mundo era família, cheio de primos. Portugal era bastante atrasado naquela época. Só a partir de 1980, quando Portugal entrou na comunidade europeia, que Portugal deu um pulo de qualidade. Então foi muito interessante. Para uma criança foi muito divertido porque eu acompanhava meu avô, subia na carroça de bois. Muito divertido, para mim e pro meu irmão. Fora que nós tínhamos parentes em tudo quanto era lugar. Naquela época, não tinha nem luz elétrica na cidade onde moravam meus pais antes. Então foi muito interessante. Manoel Horácio Francisco da Silva, nascido em 1945, em Aveiro.

As memórias de quem saiu e ficou muitos anos longe de Portugal, longe da família, estão impregnadas pela saudade e pela nostalgia. E na urgência de sanar esse desejo, a volta é sempre emocionante, como na história de Beatriz Leão Freitas, que voltou a ver as irmãs, que moravam na Madeira, após 46 anos morando no Brasil e de Cláudia Botelho que saiu de Portugal com oito anos e voltou adulta:

De repente me deu aquela vontade de ver as minhas irmãs, abraçar a minha família. Cheguei a Lisboa, ainda mais hora e meia pra chegar no Funchal, aquele aeroporto pequenininho. Eu fui com tanta alegria, quando cheguei em Lisboa, telefonei a Madeira. E já não conhecia elas. A minha irmã que não tinha nenhum bebê, a Matilde estava com uma neta. filha daquela primeira filha, que nem tinha filhos ainda. Já com 17 anos. E aquilo foi tudo uma alegria. Noite e dia, ficava-se conversando até duas horas da manhã, três, pra pôr as coisas em dia. Aí quando chegou a hora de ir embora que foi. E agora tenho que partir. Agora minha terra é lá. Minhas filhas, meus netos. Beatriz de Leão Pereira, nascida no Funchal, Ilha da Madeira, em 1924.

E esse lugar é um dos lugares assim, sabe? Que eu realmente não, eu não consigo, que tinha até um pé de mimosa, e eu fiquei fixada naquele pé de mimosa. Imagina uma árvore enorme toda amarela. Quando eu voltei novamente a Portugal depois que eu vim para aqui, eu voltei em 89. E eu fui com a minha filha mais nova e eu simplesmente na minha cabeça estava assim, sabe? E eu falei: "Gente, eu vou embora direto". Eu cheguei em Lisboa eram 4 horas da tarde. Porque eu cheguei no verão o horário lá, aí eu resolvi ir para o lugar que eu tinha nascido, que eu tinha vindo assim sem me lembrar com detalhes. Mas o único detalhe que estava na minha cabeça era esse lugar lindo, deslumbrante, com um pé de mimosa maravilhoso. E eu acabei chegando, imagina, eu viajei 400 quilômetros, 400 e poucos quilômetros, né? Tanto é que o motorista que eu contratei ele nem aguentou, né? Chegamos no meio do caminho ele passou a bola para um outro motorista. Mas eu consegui chegar no local porque estava gravado na minha memória, essa coisa aí. Esse lugar lindo. E eu fui justamente cair nesse lugar, que é uma distância enorme. Uma coisa de criança mesmo, né? Cláudia Lage Botelho, nascida em Vila Real, em 1949.

Mesmo com as saudades, esses emigrantes não cogitaram voltar a morar em Portugal

porque já haviam construído uma vida no Brasil, seja no caso de Arménio Mendes, por 
exemplo, que acabou mudando os planos de voltar a morar em Portugal, ou no caso de Perfeito Fortuna, que veio muito novo e acabou ficando sozinho no Brasil:

Meus primeiros seis anos aqui, eu não queria nem conhecer mulher, pra não me apaixonar. Porque eu tinha um propósito de ficar aqui dez anos e voltar. Eu dizia: "Se eu me casar aqui, eu não volto, eu não posso constituir família aqui, isso não pode passar na minha cabeça." Eu sempre planejei a minha vida. Então fiquei aqui seis anos, nos meus primeiros seis anos, de 63 até 69. Em 1969, seis anos depois, eu fui a Portugal, já estava fazendo três prédios, mas ainda estava com o propósito de ficar aqui mais três ou quatro anos e ir embora. Então eu conheci minha mulher, nesse passeio que eu fiz, conheci a minha mulher. Eu fiquei me correspondendo com ela, não telefonando porque não tinha dinheiro pra gastar em telefone, nem havia essa facilidade, eu fiquei me correspondendo com minha mulher, por carta, e em 71 eu voltei em Portugal, namorei mais 30 dias, me casei e vim casado. Ela adora o Brasil, não tem jeito, não tem jeito. Hoje eu tenho meus filhos brasileiros, tenho minhas noras brasileiras, está chegando o primeiro neto aí, daqui a pouco. E hoje se me disserem: "Você vai ter que ir pra Portugal", eu não vou mais. Arménio Mendes, nascido em 1944, em Chão de Couce.

Nessa época a minha família tinha ido embora e eu estava nessa escola de teatro e não queria ir embora. Ninguém me convidou pra eu ir pra Portugal. Eles arrumaram um jeito de ir, iam morar lá de volta. Vendeu tudo e ia voltar pra Portugal. Minhas irmãs queriam e tal. Mesmo se me chamasse ia ser difícil de eu ir. Não ia porque eu já estava gravando na rádio Globo, já estava com uma vida caminhando. Já querendo fazer a escola de teatro. A minha mãe depois se sentiu culpada em relação a isso. Bem, aí meu pai me deixou simplesmente uma bicicleta, e um relógio. E assim, hoje o que vem a ser assim uns 200 paus, 300 paus. E me perguntava: "Você tem onde ficar?" eu falava "Claro...". Eu não tinha onde ficar. Aí a minha mãe: "Aonde é que tu vais comer hoje?" Comer hoje? Onde é que eu vou comer hoje? É um negócio imediato. "Já almoçastes? Vai jantar aonde?" Foram embora. Na primeira noite eu dormi na rua, cara. Perfeito António Fortuna Serra Lopes, nascido em Serzedo, em 1950.

\section{Considerações finais}

As narrativas de memória são fonte inesgotável de informações para o entendimento de processos históricos, pois a construção dessas narrativas apresenta os sujeitos sociais construídos num tempo e num lugar específico. Quando trabalhamos com narrativas orais não podemos deixar de lembrar de Walter Benjamin (1994) que, no ensaio "O narrador: considerações sobre a obra de Nikolai Leskov", discute o papel do narrador e das narrativas tradicionais na modernidade. Para Benjamin instalou-se uma crise da memória e da narração, pois " a arte de narrar está definhando porque a sabedoria - o lado épico da verdade - está em extinção." (BENJAMIN, 1994, p. 201). No entanto, ele alerta que este não é um fenômeno recente ou uma característica "moderna". Para ele, o que vai causar a morte da narrativa é o surgimento do romance no início do período moderno, pois ele não alimenta as tradições orais. É preciso, dessa forma, resgatar as narrativas orais. Walter Benjamin defende que as narrativas orais se baseiam muito na experiência que é passada na transmissão de pessoa a pessoa, ou seja, 
nossa história não é somente o que narramos e o que lembramos de nossa vida, mas também de outras vidas que se entrelaçam com a nossa trajetória: as histórias de nossos antepassados que nos foram narradas por nossos pais, tios e avós. Para Benjamin, as melhores narrativas escritas são aquelas onde não há distinção entre a oralidade e a escrita, pois elas alimentam a tradição oral.

Conforme vimos, as redes familiares são extremamente importantes no processo migratório entre Portugal e Brasil no século XX. E, essas redes familiares foram sendo constituídas desde o século XIX, havendo casos, inclusive, de portugueses que voltaram a morar em Portugal nesse período e seus descendentes que migraram para o Brasil posteriormente. Esse fluxo entre os dois países, desde a independência até os dias atuais mostra que as redes familiares são extremamente importantes na escolha do país de acolhimento. Além disso, as fortes relações entre Portugal e o Brasil, que sempre foi a "joia da coroa portuguesa", apontam que os processos migratórios entre os dois países são importante fonte de estudos para a história contemporânea. Bella Feldman-Bianco (2002) aponta as semelhanças entre Brasil e Portugal como sendo ambos países semiperiféricos no capitalismo global. Ambos com trajetórias semelhantes na emigração, mas com a particularidade de o Brasil ser destino de emigrantes portugueses desde o período colonial, e Portugal passando a ser destino de emigrantes brasileiros e lusodescendentes desde os anos 90 do século XX. O caminho inverso realizado pelos brasileiros, escolhendo Portugal como "porta da Europa", é uma tendência que começou nos anos 90 e se assentou nos anos 2000.

O Portugal, que os emigrantes deixaram para trás, é quase sempre retratado de forma idílica e as memórias da infância são retratadas com nostalgia e repletas de saudades. Há quem diga que o português já nasce com o desejo de emigrar, mas que nem todos têm coragem para tal. Uma nação que teve seu auge na época dos descobrimentos, uma nação de navegadores, é construída na memória de quem ficou e de quem foi embora:

Quando eu era pequeno, da casa do meu avô, eu avistava o mar todinho. Até o que a vista alcançasse. Aquele horizonte, você vê tudo. Eu via o navio, eu ficava assim... Ele ia sumindo, sumindo, sumindo... Eu ficava imaginando o que tinha depois daquela linha. Eu queira saber o que tinha depois do que minha vista alcançava. Eu queria saber o que tinha para a frente. E assim tive sempre a ilusão de sair. Sempre tive essa ilusão de sair. Até quando eu saí. Agora, quando eu embarquei no navio, eu saí nesse mundo afora. Não sabia como estava fazendo, não sabia nada. Eu só via céu e água, dia e noite. Só. José Ramiro Fernandes Rocha, nascido no Funchal, em 1934. 


\section{Fontes orais}

Abel Gonçalves (2000). Entrevista para o projeto Museu Aberto, entrevistado por Rosali Henriques e Neuza Guerreiro de Carvalho, São Paulo, 19/08/2000.

António Alberto Saraiva (2012). Entrevista para o projeto Memórias do Comércio em São Paulo - Novos Olhares, entrevistado por Isla Nakano e Davi Sampaio, São Paulo, $16 / 08 / 2012$.

António Alves da Rocha Guimbra (1999). Entrevista para o projeto Cadeira de Barbeiro, entrevistado por Rosana Miziara, Stella Franco e Márcia Gomes, São Paulo, 26/06/1999.

Almerinda Lourenço Pontes (2003). Entrevista para o projeto Memórias do Comércio no Rio de Janeiro, entrevistada por Paula Ribeiro e Edvaldo Melo, Rio de Janeiro, 02/06/2003.

António Hermínio Garcia da Rocha Lopes (2003). Entrevista para o projeto Memórias do Comércio no Rio de Janeiro, entrevistado por Paula Ribeiro e Fábio Campelo Teixeira, no Rio de Janeiro, 26/06/2003.

Arménio Mendes (2001). Entrevista para o projeto Memórias do Comércio - Baixada Santista, entrevistado por Inês Barreto e Andréa Afonso, em Santos, 17/10/2001.

Artur Leite (2003). Entrevista para o projeto Memórias do Comércio no Rio de Janeiro, entrevistado por Fábio Campelo e Edvaldo de Melo, Rio de Janeiro, 30/ 6/ 2003.

Beatriz de Freitas Leão Pereira (2001). Entrevista para o projeto Memórias do Comércio - Baixada Santista, entrevistada por Inês Barreto e Cláudia Fonseca, em Santos, 24/10/2001.

Clarisse Diniz e Paiva (2013) Entrevista para o projeto Ponto de Cultura - Conte sua História, entrevistada por Rosana Miziara, São Paulo, 07/11/2013.

Claudia Lage Botelho (2003). Entrevista para o projeto Memórias do Comércio no Rio de Janeiro, entrevistada por Louise Gabler e Fernanda Monteiro, no Rio de Janeiro, 24/06/2003.

Fernando Lemos (2008). Entrevista para o projeto Memória da Literatura InfantoJuvenil, entrevistado por Thiago Majolo, em São Paulo, 22/04/2008.

Irene Maria Gomes Barandas (2003). Entrevista para o projeto Memórias do Comércio no Rio de Janeiro, entrevistada por André Magalhães e Louise Gabler de Souza, Rio de Janeiro, 25/06/2003.

João Augusto Reverendo de Miranda (2005) Entrevista para o projeto GERH, entrevistado por Márcia Ruiz e Stela Trédice, Itu, 30/09/2005

Joaquim Cabral Guedes (2003). Entrevista para o projeto Memórias do Comércio no Rio de Janeiro, entrevistado por Edvaldo Trajano e Fernanda Monteiro, Rio de Janeiro, $13 / 06 / 2003$. 
Cadernos CERU, Série 2, Vol. 31, n. 1, jun. 2020

José Pereira Correia Lopes (2003). Entrevista para o projeto Memórias do Comércio no Rio de Janeiro, entrevistado por Paula Ribeiro e Fábio Campelo Teixeira, Rio de Janeiro, 12/ 6/ 2003.

José Ramiro Fernandes Rocha (1996). Entrevista para o projeto Profissões em Extinção, entrevistado por Luiz André do Prado e Priscila Perazzo. São Paulo, 12/10/1996.

Manoel Horácio Francisco da Silva (2003). Entrevista para o projeto Vale Memória, entrevistado por Arnaldo Marques e Marina Gomes. Rio de Janeiro, 25/7/2003.

Manuel dos Santos Paiva (2001). Entrevista para o projeto Imigrantes - Memórias de um cotidiano, entrevistado por Stella Franco e Bia Blay. São Paulo, 27/06/2001.

Manuel Fernando Rodrigues (2001). Entrevista para o projeto Imigrantes - Memórias de um cotidiano, entrevistado por Stella Franco e Barbara Tavernard Thompson. São Paulo, 27/06/2001.

Manuel Henrique Farias Ramos (2012) Entrevista para o projeto Memórias do Comércio em São Paulo - Novos Olhares, entrevistado por Lucas Lara e Daniela Baraúna, em São Paulo, 07/05/2012.

Maria Augusta Lopes Alexandre (1994). Entrevista para o projeto Memórias do Comércio em São Paulo, entrevistada por Valéria Barbosa e Marina D'Andréa. São Paulo, 26/10/1994.

Perfeito António Fortuna Serra Lopes. Entrevista para o projeto Histórias que mudam o Mundo, entrevistado por Karen Worcman e Douglas Thomaz. São Paulo, 12/09/2009.

\section{Referências bibliográficas}

ARRUDA, José Jobson de Andrade (2009). "Migrações sociais, transmigrações políticas e receptividade imigracional". In: SOUSA, Fernando; MARTINS, Ismênia de Lima; MATOS, Izilda. Nas duas margens: portugueses no Brasil. Porto: Cepese. p. 51-67.

BENJAMIN, Walter (1994). A obra de arte na era da sua reprodutibilidade técnica. In: Magia e técnica, arte e política. Obras escolhidas vol.1. São Paulo: Brasiliense. p. 184.

FELDMAN-BIANCO, Bela (2002). "Portugueses no Brasil, brasileiros em Portugal. Antigas rotas, novos trânsitos e as construções de semelhanças e diferenças culturais". In: RAMALHO, Maria Irene; RIBEIRO, António Sousa (Orgs.). Entre ser e estar: raízes, percursos e discursos da identidade. Porto, Afrontamento. p. 143-184.

GINZBURG, Carlo (2007). "Micro-história: duas ou três coisas que sei a respeito". In: O fio e os rastros: verdadeiro, falso, fictício. São Paulo: Companhia das Letras.

LANG, Alice Beatriz da Silva Gordo; DEMARTINI, Zeila de Brito Fabri (2008). "Imigrantes portugueses em São Paulo: uma história oral". In: MATOS, Maria Izilda; SOUSA, Fernando; HECKER, Alexandre (Orgs.). Deslocamentos e histórias: os portugueses. Bauru: Edusc, 2008. p.211-224 
LEVI, Giovanni (1992). "Sobre a micro-história”. In: BURKE, Peter (Org.). A escrita da história: novas perspectivas. São Paulo: Unesp. pp. 133-198.

MENEZES, Lená Medeiros; MATOS, Maria Izilda Santos de (2017). Gênero e imigração: mulheres portuguesas em foco (Rio de Janeiro e São Paulo - XIX e XX). São Paulo: eManuscrito.

PADILLA, Beatriz; ORTIZ, Alejandra (2012). "Fluxos migratórios em Portugal: do boom migratório à desaceleração no contexto de crise. Balanços e Desafios". Revista Internacional de Mobilidade Humana, Brasília, ano XX, No 39, p. 159-184, jul./dez.

PASCAL, Maria Aparecida Macedo (2005). Portugueses em São Paulo: a face feminina da Imigração. São Paulo: Expressão \& Arte.

PEREIRA, Miriam Halpern (2009). “A emigração portuguesa para o Brasil e a geo-estratégia do desenvolvimento euro-americano". Ler História: emigração e imigração. vol 56. p. 15-25.

ROSALES, Marta Vilar (2015). As coisas da casa: cultura material, migrações e memórias familiares. Lisboa: Imprensa de Ciências Sociais.

SAYAD, Abdelmalek (1998). A Imigração ou os paradoxos da alteridade. São Paulo: Edusp.

TRUZZI, Oswaldo (2008). "Redes em processos migratórios". Tempo Social. Revista de sociologia da USP, v. 20, n. 1. p.199-219.

VAINFAS, Ronaldo (2002). Os protagonistas anônimos da História: micro-história. Rio de Janeiro: Campus. 